\title{
Complications of Surgical Treatment of Anterior Shoulder Dislocation: A Systematic Review
}

\section{Walter Hugo Brandão Nascimentoㄹ, Lailson Oliveira de Castro², Liwerbeth dos Anjos Pereira², João Paulo Pimentel de Sousa², Paulo Renan Matos Sucupira Cunha', Rodrigo Martins Silva Caetano ${ }^{3}$}

\author{
${ }^{1}$ Resident Physician in Orthopedics and Traumatology, University Hospital of the Universidade Federal do Maranhão, São Luís, \\ Brazil \\ ${ }^{2}$ Scholarship Holder, Conselho Nacional de Desenvolvimento Científico e Tecnológico (CNPq), São Luís, Brazil \\ ${ }^{3}$ Preceptor of the Medical Residency in Orthopedics and Traumatology, University Hospital of the Universidade Federal do \\ Maranhão, São Luís, Brazil \\ Email: nbhw_br@outlook.com
}

How to cite this paper: Nascimento, W.H.B., Castro, L.O., Pereira, L.A., Sousa, J.P.P., Cunha, P.R.M.S. and Caetano, R.M.S. (2017) Complications of Surgical Treatment of Anterior Shoulder Dislocation: A Systematic Review. Open Journal of Orthopedics, 7, 241-253.

https://doi.org/10.4236/ojo.2017.79026

Received: June 22, 2017

Accepted: September 1, 2017

Published: September 4, 2017

Copyright $\odot 2017$ by authors and Scientific Research Publishing Inc. This work is licensed under the Creative Commons Attribution International License (CC BY 4.0).

http://creativecommons.org/licenses/by/4.0/

cc) (i) Open Access

\begin{abstract}
Introduction: shoulder joint has the greatest range of motion in the human body. The shoulder anatomy promotes high mobility and favors relative sacrifice of articular stability, making it susceptible and more prone to events of instability and dislocation. This review aimed at identifying main complications of surgical treatment of anterior shoulder dislocation. Methodology: This systematic review was conducted according to the International Preferred Reporting Items for Systematic Reviews and Meta-Analyzes (PRISMA) guidelines. Studies which were eligible for this systematic review included: English or Spanish language, studies published from 2000, which mentioned surgical complications of anterior shoulder dislocation in their results, both in open and arthroscopic surgery. Included studies which were required to have at least 1 complication following surgical repair. Only studies from original data were included. Results: We found 228 potentially eligible studies for the survey. Through the inclusion and exclusion criteria and after consensus among reviewers, we chose 9 studies to compose the systematic review. Conclusion: Important information emerges: recurring instability, recurring dislocation, external rotation limitation and arthritis are main surgical complications of anterior shoulder dislocation.
\end{abstract}

\section{Keywords}

Surgical Complications, Anterior Shoulder Dislocation and Recurrences 


\section{Introduction}

The shoulder joint has the greatest range of motion in the human body. Its anatomy promotes high mobility [1] and favors relative sacrifice of articular stability, making it susceptible and more prone to events of instability and dislocation [2] [3]. The mechanism of injury often occurs due to a trauma that combines abduction, hyperextension and external rotation of the shoulder. This mechanism conditions the anterior glenohumeral dislocation or subluxation causing ruptures of the joint capsule and pulling of glenoid labrum in its anteroinferior portion, i.e. the Bankart lesion. The glenoid defect may be due to a primary fracture or due to a bone lesion caused by episodes of repeated subluxations or dislocations, and it is commonly observed in patients with anterior shoulder dislocation [4] [5]. The glenoid bone defect proved to alter normal shoulder kinematics, resulting in shoulder anterior instability and additional redislocation [5] [6].

The paradigm of these lesions is anterior dislocations and anterior instability. Thus, it is estimated that the shoulder dislocation has incidence of $23.9 / 100,000$, and $98 \%$ correspond to previous dislocations. With a peak of bimodal incidence, the 15 - 29 age group shows $46.8 \%$ of shoulder dislocations, with another peak of incidence in the group of $61-80$ age related to low-energy trauma [7] [8]. A review of the National Collegiate Athletic Association (NCAA) analyzed an injury surveillance system during the years 1989 to 2004 reporting 2080 glenohumeral instabilities in various sports and equating the rate of injuries in $0.12 / 1000 \mathrm{ex}$ posed athletes, most in sports such as football, wrestling and hockey [9] [10].

Articular shoulder lesions and the number of recurrences (dislocations or subluxations) associated with anterior shoulder instability are determinant in their therapeutic approach [11]. The best knowledge of contributing factors of complications in each treatment increases the high importance of preventing adverse effects resulting from therapeutic management.

In addition to the general complications of surgery and recurrent shoulder instability, other problems were described after surgical stabilization. The most commonly encountered complications are pain, loss of motion, infection, implant release, neurovascular injury, and late articular degeneration. After arthroscopic stabilization, neurovascular lesions, adhesive capsulitis and synovial fistula are found. Other complications are specific to the surgical technique used for Bankart lesion and include laxity, fractures and interlocking after using clamps, suprascapular nerve lesions and pain after transglenoid repair [12] [13].

Complications related to the surgical treatment of anterior shoulder dislocation in the orthopedic and traumatology services are common worldwide. The analysis of the current literature shows lack of consensus regarding the complications of surgical treatment of instability and anterior shoulder dislocation, and which therapeutic approach guarantees the best results, especially in relapsing situations. In this sense, this review identified main complications of surgical treatment of anterior shoulder dislocation. 


\section{Methods}

\subsection{Literature Search Strategy}

This systematic review was conducted according to the International Preferred Reporting Items for Systematic Reviews and Meta-Analyzes (PRISMA) guidelines. We performed searches on the PubMed and LILACS electronic databases in July 2017. To achieve the maximum sensitivity in the search strategy, we used the descriptor "anterior shoulder dislocation" according to the Medical Subject Headings (MeSH).

\subsection{Eligibility Criteria}

Studies eligible for this systematic review included: English or Spanish language, studies published from 2000, which mentioned surgical complications of anterior shoulder dislocation in their results, both in open and arthroscopic surgery. Included studies were required to have at least 1 complication following surgical repair. Only studies from original data were included. Abstracts, case report, qualitative study, conference presentation, editorial, review, cross-sectional study, biomechanical study, pilot study, cohort, studies addressing cancer patients, pediatric-patient studies and expert opinions were excluded.

\subsection{Qualitative Evaluation}

Two independent reviewers (L.O.C and J.P.P.S) evaluated each article and found agreement on any disagreement about including or excluding studies due to controversy in their selection. The International Preferred Reporting Items for Systematic Reviews and Meta-Analyzes (PRISMA) checklist were used to evaluate the quality of studies. Two orthopedic surgeons (W.H.B.N and P.R.M.S.S) were consulted on the included references.

\subsection{Extracted Data}

Data were extracted from texts, tables and figures of all articles included in the study.

\subsection{Selection Steps}

Procedures were organized following the International Preferred Reporting Items for Systematic Reviews and Meta-Analyzes (PRISMA) guidelines: at first, we conducted a survey of studies on the databases using the proposed descriptors; secondly, we have removed studies in duplicate; and subsequently we selected studies from the title, abstract and formation of a systematized database. In the eligibility stage, selected studies were read in full and stored in a new database. In the inclusion stage, we discussed studies according to the pertinent literature to establish consensus and divergent points in the literature and produce a critical summary summarizing the information provided by the included articles. 


\section{Results}

We found 228 potentially eligible studies for review and 4 duplicate studies were removed. Initially, reviewers L.O.C and J.P.P.S evaluated titles and abstracts of these publications, and 192 references were excluded. After selection through the abstracts, we selected 32 studies that were read in full by the two independent reviewers. The complete reading of studies resulted in the exclusion of 7 articles in the German language [14]-[20], 2 studies that did not involve surgical procedures [21] [22], 9 studies without surgical complications [23]-[31], 3 studies comparing the types of sutures [32] [33] [34], 1 study published before 2000 [35] and 1 study with impossibility of access [36]. Through the inclusion and exclusion criteria and after consensus among reviewers, 9 studies were selected to compose the systematic review [37]-[45] (Figure 1).

A total of 1016 patients were investigated in the 9 studies included in this systematic review. Open surgery was used in 175 of these patients, while arthroscopic surgery occurred in 216 patients. Forty-two patients underwent capsular arthroscopic lavage, 31 were submitted to T-plasty procedure and Bankart repair. The coracoid process transfer occurred in 219 patients and 217 were submitted to open soft tissue reconstruction. Thirty-one patients underwent modified and anatomically oriented anteroinferior capsule change and Bankart repair, and 25 patients underwent surgery using theBoytchev technique. The average follow-up was five years and eight months; minimum follow-up of one year and eight months and maximum follow-up of 13 years and four months. Papers selected for this Systematic Review are summarized in Table 1.

In this systematic review, we identified 227 surgical complications of anterior shoulder dislocation. Complications included: 22 returns of instability, 40 returns of dislocation, 1 infection, 104 osteoarthritis, 11 external rotation limitations, 2 erythema, 3 adhesive capsulitis, 8 recurrent subluxations, 5 laxity with

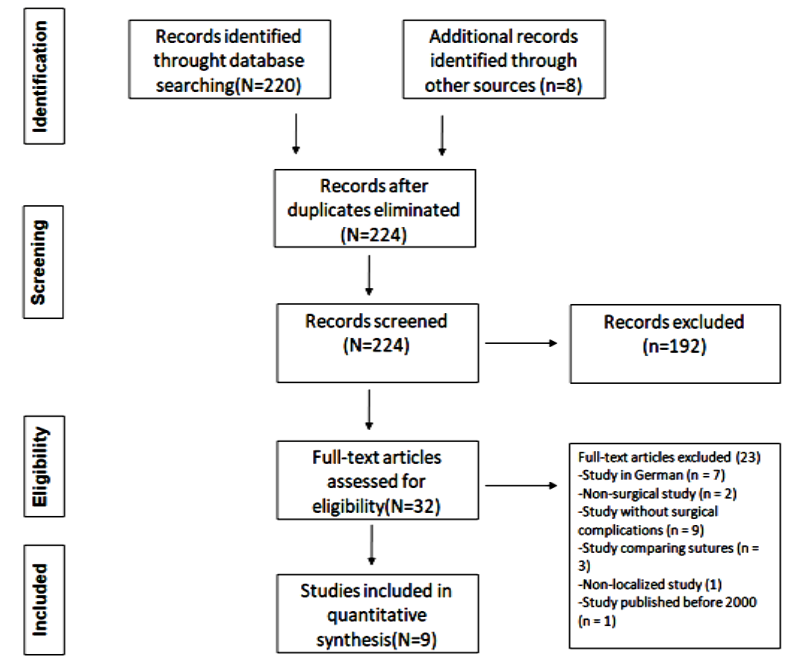

Figura 1. Preferred Reporting Items for Systematic Reviews and MetaAnalyses (PRISMA) flow diagram. From the initial 228 records, 9 studies were included. 
Table 1. Summary of articles included.

\begin{tabular}{|c|c|c|c|c|c|c|c|}
\hline Author & Year & $\begin{array}{l}\text { Level of } \\
\text { Evidence }\end{array}$ & Country & $\begin{array}{l}\text { Average } \\
\text { follow-up } \\
\text { period }\end{array}$ & $\begin{array}{c}\text { Case } \\
\text { procedure (n) }\end{array}$ & $\begin{array}{c}\text { Control } \\
\text { procedure (n) }\end{array}$ & Complications (n) \\
\hline Netto et al. & 2012 & Grade II & U.S. & $\begin{array}{l}3 \text { years and } \\
2 \text { months }\end{array}$ & $\begin{array}{l}\text { Treatment of Bankart } \\
\text { lesion by open } \\
\text { technique [25] }\end{array}$ & $\begin{array}{l}\text { Bankart lesion repair by } \\
\text { arthroscopy }[17]\end{array}$ & $\begin{array}{c}\text { Case Procedure: } \\
\text { Infection [1] } \\
\text { Control Procedure: } \\
\text { Return of instability [2] }\end{array}$ \\
\hline $\begin{array}{l}\text { Mahiroğullari } \\
\text { et al. }\end{array}$ & 2010 & & Turkey & $\begin{array}{l}2 \text { years and } \\
2 \text { months }\end{array}$ & $\begin{array}{l}\text { Treatment of } \\
\text { Bankart lesion by } \\
\text { open } \\
\text { technique [30] }\end{array}$ & $\begin{array}{c}\text { Bankart lesion repair } \\
\text { by arthroscopy }\end{array}$ & $\begin{array}{c}\text { Case Procedure: } \\
\text { Return of dislocation [1] } \\
\text { Control Procedure: } \\
\text { Return of dislocation [2] } \\
\text { Limitation of external rotation [1] }\end{array}$ \\
\hline Robinson et al. & 2008 & Grade I & U.K. & 2 years & $\begin{array}{l}\text { Bankart lesion repair } \\
\text { by } \\
\text { arthroscopic } \\
\text { technique }[42]\end{array}$ & $\begin{array}{l}\text { Capsular arthroscopic } \\
\text { lavage [42] }\end{array}$ & $\begin{array}{c}\text { Case Procedure: } \\
\text { Recurring instability [3] } \\
\text { Erythema [1] } \\
\text { Adhesive Capsulitis [2] } \\
\text { Mild Restriction [1] } \\
\text { Control Procedure: } \\
\text { Recurring instability [16] } \\
\text { Erythema [1] } \\
\text { Adhesive Capsulitis [1] } \\
\text { Mild Restriction [1] } \\
\text { Other patients: } \\
\text { Refractory stiffness }\end{array}$ \\
\hline $\begin{array}{l}\text { Andrej } \\
\text { Strahovnik e } \\
\text { Samo K. } \\
\text { Fokter }\end{array}$ & 2006 & & Slovenia & 9 years & $\begin{array}{l}\text { Treatment of } \\
\text { Bankart lesion by } \\
\text { open } \\
\text { technique. Single } \\
\text { procedure [83] }\end{array}$ & & $\begin{array}{c}\text { Single procedure: } \\
\text { Return of dislocation [5] } \\
\text { Recurring subluxation [5] } \\
\text { Stability Failure [10] } \\
\text { Laxity without instability [5] }\end{array}$ \\
\hline Jaeger et al. & 2004 & & Germany & $\begin{array}{l}1 \text { years ans } \\
8 \text { months }\end{array}$ & $\begin{array}{l}\text { T-plasty } \\
\text { procedure and } \\
\text { Bankart } \\
\text { repair [31] }\end{array}$ & $\begin{array}{l}\text { Anatomically oriented } \\
\text { and modified } \\
\text { anteroinferior capsular } \\
\text { change procedure and } \\
\text { Bankart repair [31] }\end{array}$ & $\begin{array}{c}\text { Case Procedure: } \\
\text { Return of subluxation [3] } \\
\text { Dislocation [3] } \\
\text { Control Procedure: } \\
\text { Isolated Subluxation [1] }\end{array}$ \\
\hline Buscayret et al. & 2004 & & U.S. & $\begin{array}{l}6 \text { years e } 6 \\
\text { months }\end{array}$ & $\begin{array}{l}\text { Coracoid transfer } \\
\text { procedure [279]; } \\
\text { Open soft tissue } \\
\text { reconstruction } \\
\text { [217]; Arthroscopic } \\
\text { stabilization } \\
\text { procedure [74]. }\end{array}$ & & $\begin{array}{l}\text { At least one procedure performed: } \\
\text { Arthritis with onset after surgery [104] }\end{array}$ \\
\hline Jakobsen et al. & 2007 & Grade I & Denmark & 10 years & $\begin{array}{l}\text { Treatment of Bankart } \\
\text { lesion by open } \\
\text { technique [37] }\end{array}$ & $\begin{array}{l}\text { Bankart lesion repair by } \\
\text { arthroscopy [39] }\end{array}$ & $\begin{array}{c}\text { Case Procedure: } \\
\text { Recurring dislocation [3] Pain and } \\
\text { stiffness [4] Need for surgical repair [1] } \\
\text { Control Procedure: } \\
\text { Recurring anterior dislocation [24] } \\
\text { Subjective instability [1] } \\
\text { Pain and stiffness [4] }\end{array}$ \\
\hline Bottoni et al. & 2002 & & U.S. & 3 years & $\begin{array}{l}\text { Non-surgical } \\
\text { shoulder } \\
\text { immobilization } \\
\text { technique for } 4 \\
\text { weeks followed by } \\
\text { rehabilitation [14] }\end{array}$ & $\begin{array}{l}\text { Bankart lesion repair } \\
\text { by arthroscopy [10] }\end{array}$ & $\begin{array}{l}\text { Control Procedure: } \\
\text { Repair Failure [1] Loss of } 4^{\circ} \text { in average } \\
\text { external rotation in group }[10]\end{array}$ \\
\hline $\begin{array}{l}\text { Zamora-Navas } \\
\quad \text { et al. }\end{array}$ & 2001 & & Belgium & $\begin{array}{l}13 \text { years } \\
\text { and } 4 \\
\text { months }\end{array}$ & $\begin{array}{l}\text { Boytchev technique. } \\
\text { Single procedure [25] }\end{array}$ & & $\begin{array}{l}\text { Single procedure: } \\
\text { Return of dislocation [5] } \\
\text { Restriction of mobility [5] }\end{array}$ \\
\hline
\end{tabular}


out instability, 8 cases of pain and stiffness, 2 failures of surgical repair, 5 mobility restrictions, 2 mild restrictions, 10 instability failures, 3 complete dislocations and 1 isolated subluxation (Table 2).

\section{Discussion}

Despitethe satisfactory clinical results of Latarjet procedure, the high prevalence of postoperative arthritis after the procedure is worrying. Recent research has shown a rate of development and progression to arthritis of about $23.5 \%$.

The rate of postoperative arthritis after glenohumeral instability is around $35 \%-71 \%$ in the long term. The risk for arthritis includes age of dislocation, time of surgery, and amount of pre-operative dislocations, intra-articular equipment, bone prominence and long-term follow-up [46] [47]. It is suggested that postoperative arthritis is caused not only by the Latarjet procedure but also by the natural history of glenohumeral joint. Recent evidence postulates that contact sports are associated with increased risk of developing arthritis over time, despite the low rate of recurrence. It is possible that these individuals suffer more micro-traumas on the articular surface when compared those who do not play sports [48]. In our review, 104 patients had arthritis in the postoperative period.

The surgical technique has great influence on the long-term development of arthritis. In the studies by Allain et al. and Singer et al., 32 patients submitted to

Table 2. Surgical complications of anterior shoulder dislocation.

\begin{tabular}{cc}
\hline Complications & $\mathrm{n}$ \\
\hline Infection & 1 \\
Return of instability & 22 \\
Return of dislocation & 40 \\
Limitation of external rotation & 11 \\
Erythema & 2 \\
Adhesive capsulitis & 3 \\
Mild restriction & 2 \\
Recurrent Subluxation & 8 \\
Stability failure & 10 \\
Laxity without instability & 5 \\
Complete dislocation & 3 \\
Isolated Subluxation & 1 \\
Arthritis & 104 \\
Pain and stiffness & 8 \\
Need for surgical repair & 1 \\
Repair failure & 1 \\
Mobility restriction & 5 \\
\hline
\end{tabular}


subscapular muscle tenotomy reported external rotation deficit associated with arthritis after coracoid grafting when long-term analyzed [46] [49].

Injury to shoulder cartilage is also commonly observed in association with subacromial impact and followed by rotator cuff repair. Magnetic resonance imaging after application of intra-articular contrast demonstrates moderate accuracy in the detection of cartilage lesions, such as the shoulder. Computed tomography appears as the best method for diagnosis of arthritis-associated cartilage lesions [50] [51] [52]

Septic arthritis, bursitis, periarticular soft tissue infection, and osteomyelitis represent rare complications of shoulder surgery. Conventional radiography is usually the only imaging method used to check for septic arthritis. Soft tissue edema, osteopenia, bone erosions and narrowing of articular space are radiographic signs in favor of infection. Magnetic resonance imaging shows value in the distinction between septic arthritis and synovial reaction, but it can be used in association with radiography for soft tissue infection, abscess formation and osteomyelitis [53] [54] [55].

A common complication of anterior shoulder dislocation is the recurrence of instability in about $60 \%$ of patients. Several biomechanical factors are involved in the return of this lesion; translation of humeral head into high positions is one example conferring recurrent instability [56] [57]. Studies comparing the recurrence of shoulder instability in surgical procedures with the open Latarjet technique and Bankart concluded that the recurrence of instability is about $5.9 \%$ and $23.2 \%$, respectively. On the other hand, recurrence of instability in the Latarjet arthroscopy procedures was $3.4 \%$. Latarjet arthroscopy seems to have better results in terms of prevention of recurrence and rehabilitation [58]. In our review, 22 patients presented recurring instability after surgical repair.

Common findings after rescreening of failed arthroscopies and open surgeries include uncured Bankart lesion, humeral avulsion of glenohumeral ligaments, extensive glenoid erosions, excessive capsular laxity, and reduction of humeral head retroversion or excessive retroversion of the glenoid cavity. Associated factors that may explain this high recurrence of instability following arthroscopy in our review include young patients, insufficient postoperative immobilization time, early return to contact sports, and multiple episodes of instability before immobilization [13].

Early surgical intervention reduces the risk of recurring dislocation by $6 \%$ to 23\% [59] [60]. The differences in recurring dislocation rates between open and arthroscopic surgeries are significant. The risk of recurrence is double for arthroscopically-treated patients when compared to open surgery [61]. These results are surprising considering that technological advances in arthroscopic surgeries should bring clinical improvements and decrease of recurring dislocation rates.

Previous studies have shown that soft tissue loss and stretching of the musculotendinous unit are involved with the biomechanical alteration in the glenohumeral joint balance, which are risk factors for recurring subluxation [62]. In our 
review, 9 patients had this complication.

Several studies have demonstrated loss of internal and external rotation after surgical procedure with Latarjet technique. The meta-analysis of An et al. evidenced movement restriction in both surgical repairs, Latarjet and Bankart, the latter implying about $6^{\circ}$ of significant postoperative restriction [56]. Regarding open surgery, one of the explanations for reduction or loss of external and internal rotation includes excessive capsule thickening, cut or shortening of subscapularis tendon, and especially, the development of fibrosis in the reconstructed capsulolabral complex [38]. In our review, we identified 11 patients with external rotation limitation and 7 patients with motion restriction.

The limitations of this systematic review are directly related to the quality of selected studies and their inherent biases, as well as the absence by some studies of the citation of their level of evidence [38] [40] [41] [42] [43] [45] and the non-use of control group [40] [42] [43].

\section{Conclusion}

Establishing main complications of the surgical treatment of anterior shoulder dislocation remains a challenge and important area for future research. Studies are heterogeneous, not defining specific patterns to approach in the management of complications resulting from primary anterior shoulder dislocation. However, important information emerges: recurring instability, recurring dislocation, external rotation limitation, and arthritis are major surgical complications of anterior shoulder dislocation. Recurrence of instability appears as the main surgical complication of anterior shoulder dislocation, although the number of patients is lower when compared to those with arthritis.

\section{Acknowledgements}

We thank the University Hospital of the Universidade Federal do Maranhão (HU-UFMA), COREME, Brazilian Society of Orthopedics and Traumatology, Brazilian Company for Hospital Services (Empresa Brasileira de Serviços Hospitalares-EBSERH), National Council for Scientific and Technological Development (Conselho Nacional de Desenvolvimento Científico e Tecnológico-CNPq), and Ministry of Education (Ministério da Educação-MEC).

\section{References}

[1] Millett, P.J., Clavert, P. and Warner, J.J. (2005) Open Operative Treatment for Anterior Shoulder Instability: When and Why? The Journal of Bone and Joint Surgery, 87, 419-432.

[2] Arliani, G.G., Astur Dda, C., Cohen, C., Ejnisman, B., Andreoli, C.V., Pochini, A.C., et al. (2011) Surgical versus Nonsurgical Treatment in First Traumatic Anterior Dislocation of the Shoulder in Athletes. Open Access Journal of Sports Medicine, 15, 19-24. https://doi.org/10.2147/OAJSM.S17378

[3] Mascarenhas, R., Rusen, J., Saltzman, B.M., Leiter, J., Chahal, J., Romeo, A.A, et al. (2014) Management of Humeral and Glenoid Bone Loss in Recurrent Glenohumer- 
al Instability. Advances in Orthopedics, Article ID: 640952.

[4] Brand, R.A. (2008) Recurrent Dislocation of the Shoulder Joint. Clinical Orthopaedics and Related Research, 466, 520-521. https://doi.org/10.1007/s11999-007-0105-3

[5] Skupinski, J., Piechota, M.Z., Wawrzynek, W., Maczuch, J. and Babinska, A. (2017) The Bony Bankart Lesion: How to Measure the Glenoid Bone Loss. Polish Journal of Radiology, 82, 58-63. https://doi.org/10.12659/PJR.898566

[6] Bigliani, L.U., Newton, P.M., Steinmann, S.P., Connor, P.M. and McLlveen, S.J. (1998) Glenoid Rim Lesions Associated with Recurrent Anterior Dislocation of the Shoulder. American Journal of Sports Medicine, 26, 41-45. https://doi.org/10.1177/03635465980260012301

[7] Hovelius, L., Olofsson, A., Sandstrom, B., Augustini, B.G., Krantz, L., Fredin, H., et al. (2008) Nonoperative Treatment of Primary Anterior Shoulder Dislocation in Patients Forty Years of Age and Younger. A Prospective Twenty-Five-Year Follow-Up. The Journal of Bone and Joint Surgery, 90, 945-952. https://doi.org/10.2106/JBJS.G.00070

[8] Zacchilli, M.A. and Owens, B.D. (2010) Epidemiology of Shoulder Dislocations Presenting to Emergency Departments in the United States. The Journal of Bone and Joint Surgery, 92, 542-549. https://doi.org/10.2106/JBJS.I.00450

[9] Watson, S., Allen, B. and Grant, J.A. (2016) A Clinical Review of Return-to-Play Considerations after Anterior Shoulder Dislocation. Sports Health, 8, 336-341. https://doi.org/10.1177/1941738116651956

[10] Owens, B.D., Agel, J., Mountcastle, S.B., Cameron, K.L. and Nelson, B.J. (2009) Incidence of Glenohumeral Instability in Collegiate Athletics. American Journal of Sports Medicine, 37, 1750-1754. https://doi.org/10.1177/0363546509334591

[11] Thomazeau, H., Courage, O., Barth, J., Pelegri, C., Charousset, C., Lespagnol, F., et al. (2010) Can We Improve the Indication for Bankart Arthroscopic Repair? A Preliminary Clinical Study Using the ISIS Score. Orthopaedics \& Traumatology: Surgery \& Research, 96, S77-S83.

[12] Gill, T.J. and Zarins, B. (2003) Open Repairs for the Treatment of Anterior Shoulder Instability. The American Journal of Sports Medicine, 31, 142-153.

https://doi.org/10.1177/03635465030310011001

[13] Robinson, C.M. and Dobson, R.J. (2004) Anterior Instability of the Shoulder after Trauma. The Journal of Bone and Joint Surgery. British Volume, 86, 469-479. https://doi.org/10.1302/0301-620X.86B4

[14] Pogorzelski, J., Beitzel, K., Imhoff, A.B. and Braun, S. (2016) The Mini-Open Latarjet Procedure for Treatment of Recurrent Anterior Instability of the Shoulder. Operative Orthopädie und Traumatologie, 28, 408-417.

https://doi.org/10.1007/s00064-016-0461-9

[15] Heers, G., Muller, H. and Hedtmann, A. (2012) The Role of Hyperlaxity in Open Stabilisation of Post-Traumatic Shoulder Instability. Zeitschrift für Orthopädie und Unfallchirurgie, 150, 470-476.

[16] Konrad, G.G., Rossler, V., Kreuz, P.C. and Sudkamp, N.P. (2009) Sports Activity and Proprioceptive Ability after Arthroscopic Capsulolabral Repair of Post-Traumatic Shoulder Instability. Zeitschrift für Orthopädie und Unfallchirurgie, 147, 452-456. https://doi.org/10.1055/s-0029-1185980

[17] Goebel, M. and Seebauer, L. (2008) Open Operative Treatment of Acute Glenoid Fractures Following Anterior and Posterior Shoulder Dislocation. Operative Orthopädie und Traumatologie, 20, 228-238. 
https://doi.org/10.1007/s00064-008-1305-Z

[18] Odenwald, S., Lemke, J., Bauer, G.J., Mauch, F., Brunner, U.H. and Krackhard, T. (2008) First Traumatic Anterior Shoulder Dislocation: Postoperative Results 6 Months and 2 Years after Arthroscopic Stabilization in Young Patients. Der Unfallchirurg, 111, 507-510, 512-513.

[19] Bohnsack, M., Brinkmann, T., Ruhmann, O., Schmolke, S., Ackermann, B. and Wirth, C.J. (2003) Open versus Arthroscopic Shoulder Stabilization. An Analysis of the Treatment Costs. Der Orthopäde, 32, 654-658. https://doi.org/10.1007/s00132-002-0418-6

[20] Bohnsack, M., Ruhmann, O., Borner, C., Schmolke, S. and Wirth, C.J. (2003) Arthroscopic Anterior Shoulder Stabilization Combined with Laser-Assisted Capsular Shrinkage (LACS) Compared to Other Procedures. Sportverletzung Sportschaden, 17, 26-31. https://doi.org/10.1055/s-2003-38590

[21] Turturro, F., Montanaro, A., Calderaro, C., Labianca, L., Di Sanzo, V., Carducci, A., et al. (2014) Efficacy of the Assisted Self-Reduction Technique for Acute Anterior Shoulder Dislocation. Archives of Orthopaedic and Trauma Surgery, 134, 17611765. https://doi.org/10.1007/s00402-014-2109-2

[22] Finestone, A., Milgrom, C., Radeva-Petrova, D.R., Rath, E., Barchilon, V., Beyth, S., et al. (2009) Bracing in External Rotation for Traumatic Anterior Dislocation of the Shoulder. The Bone \& Joint Journal, 91, 918-921. https://doi.org/10.1302/0301-620X.91B7.22263

[23] Damkjaer, L., Petersen, T. and Juul-Kristensen, B. (2015) Is the American Society of Shoulder and Elbow Therapists' Rehabilitation Guideline Better than Standard Care When Applied to Bankart-Operated Patients? A Controlled Study. Clinical Rehabilitation, 29, 154-164. https://doi.org/10.1177/0269215514539819

[24] Stein, T., Mehling, A.P., Reck, C., Buckup, J., Efe, T., Hoffmann, R., et al. (2011) MRI Assessment of the Structural Labrum Integrity after Bankart Repair Using Knotless Bio-Anchors. Knee Surgery, Sports Traumatology, Arthroscopy, 19, 17711779. https://doi.org/10.1007/s00167-011-1407-2

[25] Castagna, A., Borroni, M., Delle Rose, G., Markopoulos, N., Conti, M., Vinci, E., et al. (2009) Effects of Posterior-Inferior Capsular Plications in Range of Motion in Arthroscopic Anterior Bankart Repair: A Prospective Randomized Clinical Study. Knee Surgery, Sports Traumatology, Arthroscopy, 17, 188-194. https://doi.org/10.1007/s00167-008-0650-7

[26] Kirkley, A., Werstine, R., Ratjek, A. and Griffin, S. (2005) Prospective Randomized Clinical Trial Comparing the Effectiveness of Immediate Arthroscopic Stabilization versus Immobilization and Rehabilitation in First Traumatic Anterior Dislocations of the Shoulder: Long-Term Evaluation. Arthroscopy, 21, 55-63.

[27] Fabbriciani, C., Milano, G., Demontis, A., Fadda, S., Ziranu, F. and Mulas, P.D. (2004) Arthroscopic versus Open Treatment of Bankart Lesion of the Shoulder: A Prospective Randomized Study. Arthroscopy, 20, 456-462.

[28] Edmonds, G., Kirkley, A., Birmingham, T.B. and Fowler, P.J. (2003) The Effect of Early Arthroscopic Stabilization Compared to Nonsurgical Treatment on Proprioception after Primary Traumatic Anterior Dislocation of the Shoulder. Knee Surgery, Sports Traumatology, Arthroscopy, 11, 116-121. https://doi.org/10.1007/s00167-003-0346-y

[29] Itoi, E., Watanabe, W., Yamada, S., Shimizu, T. and Wakabayashi, I. (2001) Range of Motion after Bankart Repair. Vertical Compared with Horizontal Capsulotomy. The American Journal of Sports Medicine, 29, 441-445. 
https://doi.org/10.1177/03635465010290041001

[30] Larrain, M.V., Botto, G.J., Montenegro, H.J. and Mauas, D.M. (2001) Arthroscopic Repair of Acute Traumatic Anterior Shoulder Dislocation in Young Athletes. Arthroscopy, 17, 373-377. https://doi.org/10.1053/jars.2001.23226

[31] McRae, S., Leiter, J., Subramanian, K., Litchfield, R. and MacDonald, P. (2016) Randomized Controlled Trial of Arthroscopic Electrothermal Capsulorrhaphy with Bankart Repair and Isolated Arthroscopic Bankart Repair. Knee Surgery, Sports Traumatology, Arthroscopy, 24, 414-421. https://doi.org/10.1007/s00167-015-3543-6

[32] Silberberg, J.M., Moya-Angeler, J., Martin, E., Leyes, M. and Forriol, F. (2011) Vertical versus Horizontal Suture Configuration for the Repair of Isolated Type II SLAP Lesion through a Single Anterior Portal: A Randomized Controlled Trial. Arthroscopy, 27, 1605-1613.

[33] Milano, G., Grasso, A., Santagada, D.A., Saccomanno, M.F., Deriu, L. and Fabbriciani, C. (2010) Comparison between Metal and Biodegradable Suture Anchors in the Arthroscopic Treatment of Traumatic Anterior Shoulder Instability: A Prospective Randomized Study. Knee Surgery, Sports Traumatology, Arthroscopy, 18, 1785-1791. https://doi.org/10.1007/s00167-010-1212-3

[34] Magnusson, L., Ejerhed, L., Rostgard-Christensen, L., Sernert, N., Eriksson, R., Karlsson, J., et al. (2006) A Prospective, Randomized, Clinical and Radiographic Study after Arthroscopic Bankart Reconstruction Using 2 Different Types of Absorbable Tacks. Arthroscopy, 22, 143-151.

[35] Norlin, R. (1994) Use of Mitek Anchoring for Bankart Repair: A Comparative, Randomized, Prospective Study with Traditional Bone Sutures. Journal of Shoulder and Elbow Surgery, 3, 381-385.

[36] Cole, B.J., L'Insalata, J., Irrgang, J. and Warner, J.J. (2000) Comparison of Arthroscopic and Open Anterior Shoulder Stabilization. A Two to Six-Year Follow-Up Study. The Journal of Bone and Joint Surgery, 82, 1108-1114. https://doi.org/10.2106/00004623-200008000-00007

[37] Archetti Netto, N., Tamaoki, M.J., Lenza, M., dos Santos, J.B., Matsumoto, M.H., Faloppa, F., et al. (2012) Treatment of Bankart Lesions in Traumatic Anterior Instability of the Shoulder: A Randomized Controlled Trial Comparing Arthroscopy and Open Techniques. Arthroscopy, 28, 900-908.

[38] Mahirogullari, M., Ozkan, H., Akyuz, M., Ugras, A.A., Guney, A. and Kuskucu, M. (2010) Comparison between the Results of Open and Arthroscopic Repair of Isolated Traumatic Anterior Instability of the Shoulder. Acta Orthopaedica et Traumatologica Turcica, 44, 180-185. https://doi.org/10.3944/AOTT.2010.2289

[39] Robinson, C.M., Jenkins, P.J., White, T.O., Ker, A. and Will, E. (2008) Primary Arthroscopic Stabilization for a First-Time Anterior Dislocation of the Shoulder. A Randomized, Double-Blind Trial. The Journal of Bone and Joint Surgery, 90, 708721. https://doi.org/10.2106/JBJS.G.00679

[40] Strahovnik, A. and Fokter, S.K. (2006) Long-Term Results after Open Bankart Operation for Anterior Shoulder Instability. A 3- to 16-Year Follow-Up. Wiener klinische Wochenschrift, 118, 58-61. https://doi.org/10.1007/s00508-006-0551-Z

[41] Jaeger, A., Braune, C., Welsch, F., Sarikaya, Y. and Graichen, H. (2004) Postoperative Functional Outcome and Stability in Recurrent Traumatic Anteroinferior Glenohumeral Instability: Comparison of Two Different Surgical Capsular Reconstruction Techniques. Archives of Orthopaedic and Trauma Surgery, 124, 226-231. https://doi.org/10.1007/s00402-003-0601-1 
[42] Zamora-Navas, P., Borras Verdera, A., Porras Garcia, J., Padilla Marquez, A. and Linares, P. (2001) Long-Term Results of the Boytchev Procedure for the Treatment of Recurrent Dislocation of the Shoulder. Acta Orthopædica Belgica, 67, 233-235.

[43] Buscayret, F., Edwards, T.B., Szabo, I., Adeleine, P., Coudane, H. and Walch, G. (2004) Glenohumeral Arthrosis in Anterior Instability before and after Surgical Treatment: Incidence and Contributing Factors. The American Journal of Sports Medicine, 32, 1165-1172. https://doi.org/10.1177/0363546503262686

[44] Jakobsen, B.W., Johannsen, H.V., Suder, P. and Sojbjerg, J.O. (2007) Primary Repair versus Conservative Treatment of First-Time Traumatic Anterior Dislocation of the Shoulder: A Randomized Study with 10-Year Follow-Up. Arthroscopy, 23, 118-123.

[45] Bottoni, C.R., Wilckens, J.H., DeBerardino, T.M., D’Alleyrand, J.C., Rooney, R.C., Harpstrite, J.K., et al. (2002) A Prospective, Randomized Evaluation of Arthroscopic Stabilization versus Nonoperative Treatment in Patients with Acute, Traumatic, First-Time Shoulder Dislocations. The American Journal of Sports Medicine, 30 576-580. https://doi.org/10.1177/03635465020300041801

[46] Allain, J., Goutallier, D. and Glorion, C. (1998) Long-Term Results of the Latarjet Procedure for the Treatment of Anterior Instability of the Shoulder. The Journal of Bone and Joint Surgery, 80, 841-852. https://doi.org/10.2106/00004623-199806000-00008

[47] Bigliani, L.U., Weinstein, D.M., Glasgow, M.T., Pollock, R.G. and Flatow, E.L. (1995) Glenohumeral Arthroplasty for Arthritis after Instability Surgery. Journal of Shoulder and Elbow Surgery, 4, 87-94.

[48] Mizuno, N., Denard, P.J., Raiss, P., Melis, B. and Walch, G. (2014) Long-Term Results of the Latarjet Procedure for Anterior Instability of the Shoulder. Journal of Shoulder and Elbow Surgery, 23, 1691-1699.

[49] Singer, G.C., Kirkland, P.M. and Emery, R.J. (1995) Coracoid Transposition for Recurrent Anterior Instability of the Shoulder. A 20-Year Follow-Up Study. The Bone \& Joint Journal, 77, 73-76.

[50] Zanetti, M. and Hodler, J. (2004) MR Imaging of the Shoulder after Surgery. Magnetic Resonance Imaging Clinics of North America, 12, 169-183.

[51] Jost, B., Zumstein, M., Pfirrmann, C.W. and Gerber, C. (2006) Long-Term Outcome after Structural Failure of Rotator Cuff Repairs. The Journal of Bone and Joint Surgery, 88, 472-479.

[52] Guntern, D.V., Pfirrmann, C.W., Schmid, M.R., Zanetti, M., Binkert, C.A., Schneeberger, A.G., et al. (2003) Articular Cartilage Lesions of the Glenohumeral Joint: Diagnostic Effectiveness of MR Arthrography and Prevalence in Patients with Subacromial Impingement Syndrome. Radiology, 226, 165-170. https://doi.org/10.1148/radiol.2261012090

[53] Graif, M., Schweitzer, M.E., Deely, D. and Matteucci, T. (1999) The Septic versus Nonseptic Inflamed Joint: MRI Characteristics. Skeletal Radiology, 28, 616-620. https://doi.org/10.1007/s002560050562

[54] Wu, J., Covey, A. and Katz, L.D. (2006) MRI of the Postoperative Shoulder. Clinics in Sports Medicine, 25, 445-464.

[55] Woertler, K. (2007) Multimodality Imaging of the Postoperative Shoulder. European Radiology, 17, 3038-3055. https://doi.org/10.1007/s00330-007-0649-3

[56] An, V.V., Sivakumar, B.S., Phan, K. and Trantalis, J. (2016) A Systematic Review and Meta-Analysis of Clinical and Patient-Reported Outcomes Following Two Procedures for Recurrent Traumatic Anterior Instability of the Shoulder: Latarjet Pro- 
cedure vs. Bankart Repair. Journal of Shoulder and Elbow Surgery, 25, 853-863.

[57] Olds, M., Ellis, R., Donaldson, K., Parmar, P. and Kersten, P. (2015) Risk Factors Which Predispose First-Time Traumatic Anterior Shoulder Dislocations to Recurrent Instability in Adults: A Systematic Review and Meta-Analysis. British Journal of Sports Medicine, 49, 913-922. https://doi.org/10.1136/bjsports-2014-094342

[58] Longo, U.G., Loppini, M., Rizzello, G., Ciuffreda, M., Maffulli, N. and Denaro, V. (2014) Latarjet, Bristow, and Eden-Hybinette Procedures for Anterior Shoulder Dislocation: Systematic Review and Quantitative Synthesis of the Literature. Arthroscopy, 30, 1184-1211.

[59] Arciero, R.A., Wheeler, J.H., Ryan, J.B. and McBride, J.T. (1994) Arthroscopic Bankart Repair versus Nonoperative Treatment for Acute, Initial Anterior Shoulder Dislocations. The American Journal of Sports Medicine, 22, 589-594.

https://doi.org/10.1177/036354659402200504

[60] Chen, A.L., Hunt, S.A., Hawkins, R.J. and Zuckerman, J.D. (2005) Management of Bone Loss Associated with Recurrent Anterior Glenohumeral Instability. The American Journal of Sports Medicine, 33, 912-925. https://doi.org/10.1177/0363546505277074

[61] Hohmann, E., Tetsworth, K. and Glatt, V. (2017) Open versus Arthroscopic Surgical Treatment for Anterior Shoulder Dislocation: A Comparative Systematic Review and Meta-Analysis over the Past 20 Years. Journal of Shoulder and Elbow Surgery.

[62] Li, Y. and Jiang, C. (2016) The Effectiveness of the Latarjet Procedure in Patients with Chronic Locked Anterior Shoulder Dislocation: A Retrospective Study. The Journal of Bone and Joint Surgery, 98, 813-823. https://doi.org/10.2106/JBJS.15.00832

\section{Submit or recommend next manuscript to SCIRP and we will provide best service for you:}

Accepting pre-submission inquiries through Email, Facebook, LinkedIn, Twitter, etc. A wide selection of journals (inclusive of 9 subjects, more than 200 journals)

Providing 24-hour high-quality service

User-friendly online submission system

Fair and swift peer-review system

Efficient typesetting and proofreading procedure

Display of the result of downloads and visits, as well as the number of cited articles

Maximum dissemination of your research work

Submit your manuscript at: http://papersubmission.scirp.org/

Or contact ojo@scirp.org 